\title{
PERSEPSI DONATUR MENGENAI INFORMASI AKUNTANSI ORGANISASI PENGELOLAAN ZAKAT
}

\author{
Nugraheni Rintasari \\ Universitas Ahmad Dahlan \\ e-mail: nugraheni.rintasari@gmail.com
}

\begin{abstract}
ABSTRAK
This research purpose to know Donor's perception concern accounting information in zakah management organization. The aim of this research based on three survey results. First, survey by Islamic State University Syarif Hidayatullah at 2007 resulted that $75 \%$ people unwilling donate in zakah institution who they didn't know its accountability. Second, survey by PIRAC (Public Interest Research and Advocacy Center) at 2007 resulted that $47 \%$ people rejected to donate in zakah institution because their incredulity to institution. Third, survey by PIRAC (Public Interest Research and Advocacy Center) other at 2007 resulted 70\% people disposed to public fund power pattern report by institution. Accounting information in this research based on Exposure Draft Financial Accounting Standards 109 concerning Zakah, Infak, Sedekah Accounting and Zakah Management Organization Accounting Guide by Zakah Forum. This research use survey method by quissioner. Respondent of this research are Donor who donate zakah, infak, sedekah to zakah institution in Yogyakarta. This research entangles 138 respondent. Validity test for quisioner by Pearson Product Moment Methode and reliability test by Croanbach Alpha tehnique. Hypothesis testing by t-test one sample.The result shows that Donors don't need accounting information by financial statement over all but only some items in financial statement. They are cash, zakah balance, infaq balance, zakah fund, zakah give to other institution, zakah give to mustahiq, zakah fund institution, zakah give to mustahiq specifically, cash by zakah fund, zakah for office operational, and program of zakah institution.
\end{abstract}

Keyword: Donor's perception, acconting information

\section{PENDAHULUAN}

Di Indonesia lembaga yang diizinkan untuk menerima dan mengelola zakat disebut badan amil zakat atau lembaga amil zakat. Ketentuan pengelolaan zakat oleh lembaga amil zakat diatur dalam Undang Undang Nomor 38 Tahun 1999.
Pada bulan September 2008 Haji Syaikon, warga Pasuruan membagikan zakat kepada kurang lebih lima ribu warga masyarakat dan menewaskan dua puluh orang warga yang berdesak-desakan mengantri pembagian zakat (detiknews, 2008). Peristiwa tersebut mendapat respon dari berbagai kalangan. Banyak praktisi pengelola zakat menilai, pembagian zakat dalam jumlah besar secara pribadi merupakan bentuk 
ketidakpercayaan masyarakat kepada lembaga amil zakat. Hal tersebut sesuai dengan hasil survei UIN Syarif Hidayatullah yang menyebutkan bahwa $75 \%$ masyarakat enggan menyalurkan zakat pada lembaga yang tidak dikenal baik akun tabilitasnya(infopluz,2007).

Berkaitan dengan akuntabilitas lembaga zakat, Teten Kusniawan dari Forum Zakat mengatakan bahwa ketidakseragaman laporan keuangan lembaga zakat membuat masyarakat dan pemerintah tidak bisa melihat secara jelas akuntabilitas lembaga zakat (Republika, 2007). Pada Bulan Mei 2007, Tim Kerja PSAK Zakat telah berhasil membuat exposure draft (ED) untuk PSAK Zakat. Namun sampai penelitian ini dilakukan, PSAK Zakat belum ditetapkan.

Salah satu tahapan penyusunan PSAK adalah due process yaitu pihak penyusun melibatkan pihak-pihak yang berkepentingan terhadap standar untuk memberi masukan atau pendapat terhadap exposure draft standar (Tearney et all, 2004). Dalam organisasi bisnis, yang dimaksud pihak-pihak berkepentingan adalah investor, kreditur, dan pihak-pihak berkepentingan lainnya yang disebut stakeholder. Untuk OPZ, salah satu stakeholder organisasi adalah donatur yaitu pihak yang membayarkan zakat melalui lembaga. Zakat yang dibayarkan akan menjadi sumber daya bagi lembaga. Oleh karena itu, OPZ akan berupaya maksimal untuk menjaga kepercayaan donatur dalam memberikan donasi.

Dalam rangka menjaga kepercayaan donatur, OPZ berupaya untuk transparan dan akuntabel. Salah satu caranya dengan mengirimkan laporan keuangan OPZ kepada donatur. Cara lain adalah publikasi lewat website, surat kabar, atau donatur berkunjung langsung kepada OPZ.

Survei yang dilakukan PIRAC (Public Interest Research and Advocacy Center) pada tahun 2007 menyebutkan bahwa 47\% masyarakat menolak memberikan donasi karena ketidakpercayaan kepada lembaga. Hal ini menunjukkan faktor trust merupakan salah satu faktor penting untuk mendorong masyarakat memberikan donasi. Hasil survei lain dari PIRAC menyebutkan $70 \%$ masyarakat memandang perlu mengetahui laporan pendayagunaan donasi yang mereka berikan (PIRAC,2007). Belum terdapatnya laporan pendayagunaan donasi yang standar sehingga masing-masing OPZ memberikan laporan sesuai standar sendiri. Sebagai stakeholder organisasi, OPZ perlu memperhatikan kebutuhan informasi donatur terhadap laporan keuangan.

Mengingat pentingnya peran donatur dalam OPZ, peneliti tertarik untuk melakukan penelitian yang bertujuan mengetahui persepsi donatur mengenai informasi akuntansi organisasi pengelolaan zakat.

\section{REVIEW LITERATUR DAN HIPOTESIS}

Undang-Undang Nomor 38 Tahun 1999 mewajibkan OPZ untuk melakukan pelaporan keuangan bahkan menganjurkan OPZ untuk menerbitkan laporan keuangan yang telah diaudit akuntan publik. Karena belum memiliki standar akuntansi khusus, praktek akuntansi yang dilakukan OPZ berbeda-beda. Para akuntan yang bekerja di OPZ berupaya membuat kesepakatan bersama dalam melakukan praktek akuntansi. Forum Zakat lahir sebagai organisasi yang memfasilitasi OPZ untuk melakukan sinergi dan kesepakatan bersama. Salah satu kesepakatan tersebut adalah Pedoman Akuntansi Organisasi Pengelola Zakat (PA-OPZ). Sedangkan untuk pedoman pengauditan, akuntan publik mengacu pada PSAK 45 tentang Pelaporan Keuangan Organisasi Nirlaba. Meskipun pada akhirnya penggunaan PSAK 45 menimbulkan masalah karena perbedaan pandangan antara praktisi OPZ dan auditor. Di antaranya, menurut beberapa lembaga zakat dalam pencatatan keuangannya, biaya yang dikeluarkan untuk kegiatan gempa 
adalah biaya program. Dan ternyata menurut pandangan KAP (Kantor Akuntan Publik) dana untuk gempa harus dimasukkan ke biaya operasional kantor (Wahjunianto dalam Republika, 2007). Oleh karena itu banyak praktisi yang mengusulkan untuk diterbitkan PSAK Zakat.

Proses-proses penyusunan PSAK terdiri dari sepuluh tahapan, yaitu: pertama, identifikasi isu-isu standar yang akan dikembangkan menjadi standar. Berikutnya mengkonsultasikanisudengan Dewan Konsultatif Standar Akuntansi Keuangan (DKSAK). Ketiga, membentuk tim kecil atau tim penyusun dalam DSAK. Selanjutnya Tim Kecil atau Tim Penyusun melakukan riset terbatas dan menyusun konsep awal exposure draf. Berikutnya pembahasan konsep exposure draft dalam DSAK dilanjutkan dengan penerbitan dan pengedaran exposure draft kepada para konstituen. Ketujuh, pelaksanaan Public Hearing, Selanjutnya kedelapan, pembahasan setelah public hearing atas tanggapan dan masukan terhadap ED. Berikutnya pengecekan akhir (final checking). Dan terakhir, persetujuan/pengesahan ED PSAK menjadi PSAK.

Pada Bulan Mei 2007, Tim Penyusun PSAK Zakat telah berhasil merumuskan Exposure Draft (ED) PSAK 109 mengenai Akuntansi Zakat dan Infak/Sedekah. Sebelum merumuskan ED, Tim Penyusun PSAK Zakat telah melalui enam tahapan termasuk melakukan riset terbatas dalam penyusunan standar. Hal tersebut menjelaskan bahwa tim penyusun telah mengkaji materimateri dalam ED sesuai kebutuhan penggunanya.

Seperti telah disebutkan di atas bahwa survei PIRAC tahun 2007 menghasilkan temuan $70 \%$ masyarakat menginginkan laporan pendayagunaan dana publik oleh lembaga. Tetapi belum ada penelitian lebih lanjut mengenai kandungan informasi dalam laporan pendayagunaan. Dalam rangka menjawab rumusan masalah mengenai persepsi donatur mengenai informasi akuntansi organisasi pengelolaan zakat, penelitian ini men- gacu pada ED PSAK 109. Alasan pengacuan ini adalah karena apabila ditetapkan menjadi PSAK 109 Zakat maka akan menjadi standar akuntansi setiap OPZ.

Tujuan laporan keuangan OPZ disebutkan dalam PA-OPZ adalah menyediakan informasi untuk pengguna dalam pengambilan keputusan ekonomi yang rasional. Pihak pengguna memiliki kepentingan bersama dalam rangka menilai jasa yang diberikan OPZ dan kemampuannya untuk terus memberikan jasa tersebut. Kemampuan OPZ untuk memberikan jasa berkelanjutan dapat diungkapkan melalui laporan posisi keuangan atau neraca. Dalam ED juga disebutkan bahwa salah satu komponen laporan keuangan yang lengkap dari amil adalah neraca. Pengguna yang dimaksud dalam penelitian ini adalah donatur.

Dari uraian di atas, penelitian ini mengajukan hipotesis :

$\mathrm{H}_{1}$ : Donatur memiliki persepsi bahwa informasi neraca dibutuhkan dalam organisasi pengelolaan zakat

Pengelolaan zakat, infak, dan sedekah mengacu pada Al Qur'an yang secara teknis telah dicontohkan oleh Rasulullah Muhammad SAW. Seiring perkembangan zaman dan teknologi serta kondisi masyarakat, pola pengelolaan zakat pun mengalami perkembangan dengan tidak keluar dari jalur yang ada. Untuk memudahkan teknis pengelolaan dana zakat, infak, sedekah, para ahli fiqih banyak menulis buku-buku yang berkaitan dengan zakat dan pengelolaannya sebagai referensi. Salah satu acuan yang dijadikan dalam referensi penelitian ini adalah Dr. Yusuf Qardawi.

Dari segi pengelolaan, zakat memiliki aturan khusus dibandingkan dengan infak/ sedekah. Zakat hanya diperuntukkan bagi delapan golongan (mustahiq). Pertama, fakir yaitu masyarakat yang tidak mempunyai harta atau penghasilan layak dalam memenuhi kebutuhan sandang, pangan, tempat tinggal dan kebutuhan pokok lainnya. Kedua, miskin yaitu masyarakat yang mempunyai harta atau 
penghasilan layak tetapi tidak mencukupi. Sasaran pertama zakat adalah menghapuskan kemiskinan dan kemlaratan. Oleh karena itu dua golongan tersebut mendapatkan prioritas utama dalam penyaluran dana zakat.

Golongan ketiga adalah amil zakat, yaitu pihak yang melakukan segala kegiatan urusan zakat, mulai dari para pengumpul sampai kepada bendahara dan para penjaganya, juga mulai dari pencatat sampai kepada penghitung yang mencatat keluar masuk zakat dan membagi kepada para mustahiknya. Amil zakat dapat diartikan sebagai OPZ. Zakat yang diberikan bukan merupakan pertolongan sebagaimana untuk golongan lainnya melainkan untuk imbalan atas pekerjaannya. Bagian untuk amil adalah sebesar golongan lainnya. Dalam praktek di OPZ, bagian untuk amil digunakan untuk biaya pegawai juga termasuk biaya-biaya lainnya yang merupakan sarana pendukung operasional OPZ.

Golongan keempat dari mustahik zakat adalah muallaf, yaitu golongan yang diharapkan kecenderungan hatinya atau keyakinannya dapat bertambah terhadap Islam, atau terhalangnya niat jahat mereka atas kaum Muslimin, atau harapan akan adanya kemanfaatan mereka dalam membela dan menolong kaum Muslimin dari musuh. Secara ringkas, Imam Syafii dalam Qardawi (2007) menyebutkan bahwa muallaf adalah golongan yang baru saja memeluk agama Islam.

Golongan kelima adalah riqob atau budak. Artinya zakat dapat digunakan untuk membebaskan golongan yang menjadi budak agar merdeka. Dalam praktek sekarang, golongan ini jarang ada. Golongan keenam adalah gharim atau orang yang berutang. Hutang yang dimaksud adalah hutang untuk keperluan diri sendiri ataupun untuk kepentingan masyarakat banyak. Lebih khusus dijelaskan Qardawi (2007) golongan ini termasuk korban bencana. Golongan ketujuh adalah sabilillah yaitu golongan yang melakukan amal perbuatan ikhlas dalam rangka beribadah kepada Allah baik pribadi ataupun kemasyarakatan. Dan golongan kedelapan adalah ibnu sabil yaitu musafir atau orang yang melintas dari satu daerah ke daerah lainnya.

Untuk dana infak/sedekah tidak ada ketentuan dalam pengelolaan sehingga merupakan kebijakan masing-masing OPZ dalam penyalurannya. Terkecuali ada permintaan khusus dari donatur. Sebagai contoh donatur meminta agar infaknya disalurkan ke daerah bencana tertentu. Sebagaimana dana zakat, OPZ juga berhak atas sebagian dana infak/sedekah walaupun tidak ada ketentuan khusus. OPZ harus menetapkan secara proporsional mengenai dana infak/sedekah untuk amil. Kebijakan proporsi tersebut dapat diungkapkan melalui laporan keuangan.

Penelitian Ine Dwiyanti(2007) menemukan penerapan akuntansi dana berpengaruh positif terhadap akuntabilitas keuangan OPZ. Hal ini sejalan dengan penelitian sebelumnya yang dilakukan Arianto Budiman (2004) dan Mahdi Darwis (2005) yang menemukan terdapat korelasi positif antara penerapan akuntansi dana terhadap akuntabilitas keuangan (infopluz,2007).

Dalam PA-OPZ disebutkan bahwa akuntansi dana merupakan sistem akuntansi yang memisahkan dana menurut peruntukannya sehingga masing-masing merupakan entitas akuntansi yang mampu menunjukkan keseimbangan antara penggunaan dan penerimaan dana. OPZ memiliki setidaknya tiga sumber dana, yaitu zakat, infak, dan sedekah. Untuk infak dan sedekah kecuali dikhususkan oleh donatur, tidak ada aturan dalam penggunaannya. Sedangkan zakat memiliki aturan dalam penggunaan dananya. Informasi mengenai penerimaan dari masing-masing jenis dana serta penggunaannya dapat diungkapkan melalui laporan perubahan dana. Dalam ED juga disebutkan bahwa salah satu komponen laporan keuangan yang lengkap dari amil adalah laporan penggunaan dana. 
Dari uraian di atas, penelitian ini mengajukan hipotesis :

$\mathrm{H}_{2}$ : Donatur memiliki persepsi bahwa informasi laporan perubahan dana dibutuhkan dalam organisasi pengelolaan zakat

Weinstein (1978) mengungkapkan akuntansi dana memang layak diterapkan pada organisasi non profit tetapi tidak mutlak. Artinya lembaga tersebut berhak membuat laporan keuangan sesuai kebutuhan. Dalam ED disebutkan bahwa salah satu komponen laporan keuangan yang lengkap dari amil adalah laporan perubahan aset kelolaan. ED mengatur pos-pos dalam Laporan Perubahan Aset Kelolaan tetapi tidak terbatas pada aset kelolaan yang termasuk aset lancar dan tidak lancar termasuk akumulasi penyusutan. Laporan perubahan dalam aktiva atau aset menggambarkan peningkatan atau penurunan kekayaan berdasarkan prinsip pengukuran tertentu yang diadopsi dan harus diungkapkan dalam laporan keuangan (Bastian, 2006).

Dari uraian di atas, penelitian ini mengajukan hipotesis:

$\begin{aligned} \mathrm{H}_{3}: & \text { Donatur memiliki persepsi bahwa } \\ & \text { informasi laporan perubahan aset } \\ & \text { kelolaan dibutuhkan dalam organisasi } \\ & \text { pengelolaan zakat }\end{aligned}$

Dalam ED, disebutkan bahwa salah satu komponen laporan keuangan yang lengkap dari amil adalah laporan arus kas. PA-OPZ menjelaskan tujuan utama laporan arus kas adalah menyediakan dasar untuk para pengguna laporan keuangan dalam menilai OPZ dalam menghasilkan kas dan setara kas serta kebutuhan OPZ untuk menghasilkan arus kas tersebut. ED tidak menjelaskan secara rinci mengenai arus kas tetapi mengacu pada PSAK No. 2 mengenai Laporan Arus Kas.

Dari uraian di atas, penelitian ini mengajukan hipotesis:

$\mathrm{H}_{4}$ : Donatur memiliki persepsi bahwa informasi laporan arus kas dibutuhkan dalam organisasi pengelolaan zakat
Dalam laporan keuangan terdapat informasi-informasi pendukung yang tidak dimuat tetapi merupakan bagian tak terpisahkan. Sebagai contoh gambaran umum mengenai OPZ dan pengungkapan hal-hal penting lainnya yang berguna untuk pengambilan keputusan. Selain itu penjelasan mengenai program-program yang sedang dijalankan OPZ. Sudewo (2004) mengungkapkan bahwa jatuh bangunnya OPZ terletak pada kreativitas Divisi Pendayagunaan. Bagaimana sebuah OPZ memanfaatkan dana publik diterimanya menimbulkan keingintahuan para donatur. Semakin menarik program yang diusung oleh sebuah OPZ, donatur semakin tertarik menyalurkan dananya. Informasi tersebut dimuat dalam catatan atas laporan keuangan. ED menyebutkan salah satu komponen laporan keuangan yang lengkap dari amil adalah Catatan atas laporan Keuangan.

Dari uraian di atas, penelitian ini mengajukan hipotesis:

$\mathrm{H}_{5}$ : Donatur memiliki persepsi bahwa informasi catatan atas laporan keuangan dibutuhkan dalam organisasi pengelolaan zakat

\section{METODE PENELITIAN}

Penelitian ini menggunakan data primer yang diperoleh melalui kuesioner. Populasi penelitian ini adalah donatur yang berlokasi di Propinsi Daerah Istimewa Yogyakarta. Pengambilan sampel dengan metode purposive sampling. Pertimbangan yang digunakan adalah donatur yang rutin dan berkala dengan periode tertentu menyalurkan dana ZIS.

Dari 31 OPZ yang terdaftar di Forum Zakat berlokasi di Propinsi DIY, peneliti mengambil OPZ dengan potensi pendapatan terbesar sebagai lokasi penyebaran kuesioner selain donatur independen. 
Tabel 1

Distribusi Kuesioner

\begin{tabular}{|l|l|l|l|}
\hline No. & \multicolumn{1}{|c|}{ Nama OPZ } & $\begin{array}{c}\text { Jumlah } \\
\text { Disebarkan }\end{array}$ & $\begin{array}{c}\text { Jumlah } \\
\text { Kembali }\end{array}$ \\
\hline 1. & Dompet Dhuafa Jogja & 15 & 12 \\
\hline 2. & $\begin{array}{l}\text { Dompet Peduli Umat } \\
\text { Daarut Tauhid }\end{array}$ & 15 & 13 \\
\hline 3. & $\begin{array}{l}\text { Rumah ZIS } \\
\text { Universitas Gadjah } \\
\text { Mada }\end{array}$ & 15 & 6 \\
\hline 4. & $\begin{array}{l}\text { Lumbung Zakat } \\
\text { Indonesia }\end{array}$ & 15 & 10 \\
\hline 5. & $\begin{array}{l}\text { Badan Amil Zakat } \\
\text { Kota Yogyakarta }\end{array}$ & 40 & 36 \\
\hline 6. & $\begin{array}{l}\text { Lembaga Amil } \\
\text { Zakat Infaq Sedekah } \\
\text { Muhammadiyah }\end{array}$ & 15 & 15 \\
\hline 7. & $\begin{array}{l}\text { Lembaga Amil Zakat } \\
\text { Universitas Islam } \\
\text { Indonesia }\end{array}$ & 10 & 8 \\
\hline 8. & $\begin{array}{l}\text { Rumah Zakat } \\
\text { Indonesia }\end{array}$ & 10 & 13 \\
\hline 9. & $\begin{array}{l}\text { Pos Keadilan Peduli } \\
\text { Ummat }\end{array}$ & 15 & 39 \\
\hline 10. & Independen & 40 & 160 \\
\hline & Jumlah & 190 & 8 \\
\hline
\end{tabular}

Sumber: data primer yang diolah

\section{Definisi Operasional dan Pengukuran Variabel}

Variabel penelitian ini adalah persepsi donatur mengenai informasi akuntansi organisasi pengelola zakat. Informasi akuntansi dalam penelitian ini mengacu pada ED PSAK 109. Responden harus menunjukkan perlakuannya dengan skala likert 1-5. Angka 1 menunjukkan kategori "sangat tidak penting". Angka 2 menunjukkan kategori "tidak penting". Angka 3 menunjukkan kategori "ragu-ragu'. Angka 4 menunjukkan kategori "penting". Angka 5 menunjukkan kategori "sangat penting". Informasi akuntansi OPZ diturunkan menjadi lima variabel, yaitu :

1. (Neraca) Laporan Posisi Keuangan

Kuesioner tersebut berisi 13 butir pertanyaan, yaitu : Jumlah kas yang dimiliki,
Kekayaan yang setara dengan kas, Jumlah piutang, Jumlah bantuan yang berupa barang bukan aktiva tetap untuk disalurkan pada pihak ketiga, Aset tetap, Pinjaman kepada lembaga lain, Pinjaman kepada individu lain, Biaya yang masih harus dibayar, Imbalan kerja yang masih harus dibayar, Saldo dana zakat, Saldo dana infak, Saldo dana amil, Saldo dana nonhalal.

2. Laporan Perubahan Dana

Kuesioner tersebut berisi 16 butir pertanyaan, yaitu: Dana zakat yang diterima,Dana amil dari zakat,Dana zakat tersalur ke lembaga lain, Dana zakat tersalur pada penerima zakat, Dana infak dikhususkan, Dana infak tidak dikhususkan, Dana infak dikhususkan tersalur, Dana infak tidak dikhususkan tersalur,Dana amil dari infak, Penggunaan dana amil, Penerimaan dana nonhalal, Penggunaan dana nonhalal, Penerimaan zakat perseorangan, Penerimaan zakat dari lembaga, Penyaluran zakat lebih rinci, dan Penggunaan dana amil lebih rinci.

3. Laporan Perubahan Aset Kelolaan

Kuesioner tersebut berisi 2 butir pertanyaan, yaitu: Jumlah kekayaan yang dikelola lembaga dan Jumlah perubahan kekayaan yang dikelola.

4. Laporan Arus Kas

Kuesioner tersebut berisi 6 butir pertanyaan, yaitu: Total penggunaan dana zakat, infak, sedekah, Jumlah kas dari investasi, Jumlah kas yang digunakan untuk investasi, Jumlah kas dari pembiayaan, dan Jumlah kas yang digunakan untuk pembiayaan

5. Catatan Atas Laporan Keuangan

Kuesioner tersebut berisi 5 butir pertanyaan,yaitu: Struktur organisasi, Nomor dan akte pendirian organisasi, Program yang sedang dijalankan, Kebijakan akuntansi yang digunakan, dan Penjelasan atas pos laporan keuangan. 


\section{HASIL PENELITIAN DAN PEMBAHASAN}

\section{Uji Validitas}

Uji validitas dalam penelitian ini menggunakan metode Pearson Product Moment dengan bantuan Statistical Package for Social Science 17 For Windows. Dengan total responden 34, taraf kesalahan $5 \%$ maka diperoleh $\mathrm{r}$ tabel 0,344 . Hasil uji validitas yang dilakukan terhadap kuesioner untuk variabel Neraca adalah sebagai berikut:

Tabel 2

Hasil Uji Validitas untuk Variabel Neraca

\begin{tabular}{|c|c|c|}
\hline Item pertanyaan & Nilai korelasi & Keterangan \\
\hline $\begin{array}{l}\text { Jumlah kas } \quad \text { yang } \\
\text { dimiliki }\end{array}$ & 0,744 & Signifikan \\
\hline $\begin{array}{l}\text { Kekayaan yang setara } \\
\text { dengan kas }\end{array}$ & 0,823 & Signifikan \\
\hline Jumlah piutang & 0,794 & Signifikan \\
\hline $\begin{array}{l}\text { Jumlah bantuan yang } \\
\text { berupa barang bukan } \\
\text { aktiva tetap untuk } \\
\text { disalurkan pada pihak } \\
\text { ketiga }\end{array}$ & 0.680 & Signifikan \\
\hline Aset tetap & 0,748 & Signifikan \\
\hline $\begin{array}{ll}\text { Pinjaman } & \text { kepada } \\
\text { lembaga lain } & \end{array}$ & 0,742 & Signifikan \\
\hline $\begin{array}{ll}\text { Pinjaman kepada } \\
\text { individu lain }\end{array}$ & 0,654 & Signifikan \\
\hline $\begin{array}{l}\text { Biaya yang masih } \\
\text { harus dibayar }\end{array}$ & 0,779 & Signifikan \\
\hline $\begin{array}{l}\text { Imbalan kerja yang } \\
\text { masih harus dibayar }\end{array}$ & 0,656 & Signifikan \\
\hline Saldo Dana Zakat & 0,781 & Signifikan \\
\hline Saldo Dana Infak & 0,743 & Signifikan \\
\hline Saldo Dana Amil & 0,538 & Signifikan \\
\hline Saldo Dana Non halal & 0,301 & Tidak signifikan \\
\hline
\end{tabular}

Sumber : Data Primer yang diolah

Dari hasil pengolahan kuesioner di atas dapat dijelaskan bahwa item saldo dana non halal tidak signifikan. Hal tersebut berarti item saldo dana non halal tidak dapat digunakan untuk mengukur Neraca. Oleh karena itu item tersebut tidak akan digunakan dalam kuesioner penelitian. Hasil uji validitas yang dilakukan terhadap kuesioner untuk variabel Laporan Perubahan Dana adalah sebagai berikut:

Tabel 3

Hasil Uji Validitas untuk Variabel Laporan Perubahan Dana

\begin{tabular}{|l|l|l|}
\hline Item pertanyaan & $\begin{array}{l}\text { Nilai } \\
\text { korelasi }\end{array}$ & Keterangan \\
\hline $\begin{array}{l}\text { Dana zakat yang } \\
\text { diterima }\end{array}$ & 0,637 & Signifikan \\
\hline $\begin{array}{l}\text { Dana amil dari } \\
\text { zakat }\end{array}$ & 0,747 & Signifikan \\
\hline $\begin{array}{l}\text { Dana zakat tersalur } \\
\text { ke lembaga lain }\end{array}$ & 0,510 & Signifikan \\
\hline $\begin{array}{l}\text { Dana zakat tersalur } \\
\text { pada penerima } \\
\text { zakat }\end{array}$ & 0,676 & Signifikan \\
\hline $\begin{array}{l}\text { Dana Infak } \\
\text { dikhususkan }\end{array}$ & 0,730 & Signifikan \\
\hline $\begin{array}{l}\text { Dana Infak tidak } \\
\text { dikhususkan }\end{array}$ & 0,766 & Signifikan \\
\hline $\begin{array}{l}\text { Dana Infak } \\
\text { dikhususkan } \\
\text { tersalur }\end{array}$ & 0,690 & Signifikan \\
\hline $\begin{array}{l}\text { Dana Infak tidak } \\
\text { dikhususkan } \\
\text { tersalur }\end{array}$ & 0,780 & Signifikan \\
\hline $\begin{array}{l}\text { Dana amil dari } \\
\text { Infak }\end{array}$ & 0,681 & Signifikan \\
\hline $\begin{array}{l}\text { Penggunaan dana } \\
\text { amil }\end{array}$ & 0,694 & Signifikan \\
\hline $\begin{array}{l}\text { Penerimaan dana } \\
\text { non halal }\end{array}$ & Sifan \\
\hline Sumber data prme yang
\end{tabular}

Sumber: data primer yang diolah 
Tabel 3

Hasil Uji Validitas untuk Variabel Laporan Perubahan Dana

(lanjutan)

\begin{tabular}{|l|l|l|}
\hline Item pertanyaan & $\begin{array}{l}\text { Nilai } \\
\text { korelasi }\end{array}$ & Keterangan \\
\hline $\begin{array}{l}\text { Penggunaan dana non } \\
\text { halal }\end{array}$ & 0,760 & Signifikan \\
\hline $\begin{array}{l}\text { Penerimaan zakat } \\
\text { perseorangan }\end{array}$ & 0,524 & Signifikan \\
\hline $\begin{array}{l}\text { Penerimaan zakat dari } \\
\text { lembaga }\end{array}$ & 0,708 & Signifikan \\
\hline $\begin{array}{l}\text { Penyaluran dana zakat } \\
\text { secara rinci }\end{array}$ & 0,573 & Signifikan \\
\hline $\begin{array}{l}\text { Penggunaan dana amil } \\
\text { secara rinci }\end{array}$ & 0,629 & Signifikan \\
\hline
\end{tabular}

Sumber: data primer yang diolah

Dari tabel 3 di atas dapat dilihat bahwa seluruh item kuesioner signifikan sehingga dapat digunakan untuk penelitian. Hasil uji validitas yang dilakukan terhadap kuesioner untuk variabel Laporan Perubahan Aset Kelolaan adalah sebagai berikut:

Tabel 4

Hasil Uji Validitas untuk

Variabel Laporan Perubahan Aset Kelolaan

\begin{tabular}{|l|l|l|}
\hline Item pertanyaan & $\begin{array}{l}\text { Nilai } \\
\text { korelasi }\end{array}$ & Keterangan \\
\hline $\begin{array}{l}\text { Jumlah kekayaan yang } \\
\text { dikelola lembaga }\end{array}$ & 0,965 & Signifikan \\
\hline $\begin{array}{l}\text { Jumlah perubahan kekayaan } \\
\text { yang dikelola lembaga }\end{array}$ & 0,962 & Signifikan \\
\hline
\end{tabular}

Sumber: data primer yang diolah
Dari tabel 4 di atas dapat dilihat bahwa seluruh item kuesioner signifikan sehingga dapat digunakan untuk penelitian.

Hasil uji validitas yang dilakukan terhadap kuesioner untuk variabel Laporan Arus Kas adalah sebagai berikut:

Tabel 5

\section{Hasil Uji Validitas untuk Variabel Laporan} Arus Kas

\begin{tabular}{|l|l|l|}
\hline Item pertanyaan & $\begin{array}{l}\text { Nilai } \\
\text { korelasi }\end{array}$ & Keterangan \\
\hline $\begin{array}{l}\text { Kas yang berasal dari zakat, } \\
\text { infaq/sedekah }\end{array}$ & 0,871 & Signifikan \\
\hline $\begin{array}{l}\text { Penggunaan dana zakat, } \\
\text { infaq/sedekah termasuk untuk } \\
\text { operasional kantor }\end{array}$ & 0,648 & Signifikan \\
\hline $\begin{array}{l}\text { Kas yang diperoleh dari } \\
\text { investasi termasuk dari } \\
\text { penjualan aktiva tetap seperti } \\
\text { gedung }\end{array}$ & 0,921 & Signifikan \\
\hline $\begin{array}{l}\text { Kas yang digunakan untuk } \\
\text { investasi termasuk pembelian } \\
\text { aktiva tetap seperti tanah }\end{array}$ & 0,941 & Signifikan \\
\hline $\begin{array}{l}\text { Kas yang diterima dari } \\
\text { kegiatan pembiayaan } \\
\text { misalnya pinjaman dari } \\
\text { lembaga lain }\end{array}$ & 0,927 & Signifikan \\
\hline $\begin{array}{l}\text { Kas yang digunakan untuk } \\
\text { kegiatan pembiayaan }\end{array}$ & 0,914 & Signifikan \\
\hline
\end{tabular}

Sumber: data primer yang diolah

Dari tabel 9 di atas dapat dilihat bahwa seluruh item kuesioner signifikan sehingga dapat digunakan untuk penelitian.

Hasil uji validitas yang dilakukan terhadap kuesioner untuk variabel Catatan atas Laporan Keuangan adalah sebagai berikut: 
Tabel 6

\section{Hasil Uji Validitas untuk Variabel}

Catatan Atas Laporan Keuangan

\begin{tabular}{|l|l|l|}
\hline Item pertanyaan & $\begin{array}{l}\text { Nilai } \\
\text { korelasi }\end{array}$ & Keterangan \\
\hline Struktur Organisasi & 0,809 & Signifikan \\
\hline $\begin{array}{l}\text { Nomer dan akte pendirian } \\
\text { organisasi }\end{array}$ & 0,833 & Signifikan \\
\hline $\begin{array}{l}\text { Program-program yang } \\
\text { sedang dijalankan }\end{array}$ & 0,598 & Signifikan \\
\hline $\begin{array}{l}\text { Kebijakan akuntansi yang } \\
\text { digunakan dalam pembuatan } \\
\text { laporan keuangan }\end{array}$ & 0,899 & Signifikan \\
\hline $\begin{array}{l}\text { Penjelasan atas pos-pos } \\
\text { laporan keuangan misalnya } \\
\text { pengertian dana zakat, dana } \\
\text { nonhalal }\end{array}$ & 0,894 & Signifikan \\
\hline
\end{tabular}

Sumber : data primer yang diolah

Dari tabel 6 di atas dapat dilihat bahwa seluruh item kuesioner signifikan sehingga dapat digunakan untuk penelitian.

\section{Uji Reliabilitas}

Untuk uji reliabilitas penelitian ini menggunakan uji statistik Croanbach Alpha dengan bantuan Statistical Package for Social Science 17 For Windows.

Hasil uji reliabilitas yang dilakukan terhadap kuesioner untuk semua variabel adalah sebagai berikut:

\section{Tabel 7}

Hasil Uji Realiabilitas

\begin{tabular}{|l|l|l|}
\hline Item pertanyaan & Croanbach Alpha & Keterangan \\
\hline Neraca & 0,899 & Reliabel \\
\hline Laporan Perubahan Dana & 0,920 & Reliabel \\
\hline $\begin{array}{l}\text { Laporan Perubahan Aset } \\
\text { Kelolaan }\end{array}$ & 0,923 & Reliabel \\
\hline Laporan Arus Kas & 0,934 & Reliabel \\
\hline $\begin{array}{l}\text { Catatan atas Laporan } \\
\text { Keuangan }\end{array}$ & 0,872 & Reliabel \\
\hline
\end{tabular}

Sumber: data primer yang diolah
Dari tabel 7 di atas dapat disimpulkan bahwa seluruh item kuesioner dinyatakan reliabel sehingga dapat digunakan untuk penelitian.

\section{Pengujian Hipotesis}

Untuk pengujian hipotesis, penelitian ini menggunakan t-test one sample. Data yang dimaksud adalah mean skor responden dari variabel neraca tiap-tiap responden. Harga $t$ hitung selanjutnya dibandingkan dengan $t$ tabel. Apabila $t$ hitung lebih besar dari $t$ tabel maka $\mathrm{H}_{0}$ ditolak. Demikian juga sebaliknya, apabila $\mathrm{t}$ hitung lebih kecil dari $\mathrm{t}$ tabel maka $\mathrm{H}_{0}$ tidak dapat ditolak. Harga t tabel dengan dk 137 dan $\alpha$ 5\% diperoleh $t$ tabel 1,645. Secara statistik, hipotesis dapat ditunjukkan sebagai berikut:

$$
\begin{array}{ll}
\mathrm{H}_{0} & : \mu<4 \\
\mathrm{H}_{1} & : \mu \geq 4
\end{array}
$$

\section{Pengujian Hipotesis I}

$\mathrm{H}_{1}$ : Donatur memiliki persepsi bahwa informasi neraca dibutuhkan dalam organisasi pengelolaan zakat

\section{Tabel 8}

\begin{tabular}{|c|c|c|c|c|c|}
\hline & \multicolumn{5}{|c|}{ Test Value $=4$} \\
\hline & $\mathrm{t}$ & df & $\begin{array}{l}\text { Sig. } \\
\text { (2-tailed) }\end{array}$ & $\begin{array}{l}\text { Mean } \\
\text { Difference }\end{array}$ & $\begin{array}{l}95 \% \text { Confidence } \\
\text { Interval of the } \\
\text { Difference }\end{array}$ \\
\hline & & & & & \begin{tabular}{|l|l|} 
Lower & Upper \\
\end{tabular} \\
\hline Neraca & 1.552 & 137 & .123 & .08275 & -.0227 \\
\hline
\end{tabular}

\section{t-test one sampel untuk Variabel Neraca}

Sumber: data primer yang diolah

Dari tabel 8, dapat diketahui bahwa nilai t hitung adalah 1,552. Dengan demikian t hitung lebih kecil dari $\mathrm{t}$ tabel yang berarti $\mathrm{H}_{0}$ tidak dapat ditolak. Artinya hipotesis I yang menyatakan bahwa Neraca merupakan kebutuhan informasi bagi pengguna tidak dapat didukung.

\section{Pengujian Hipotesis II}

$\mathrm{H}_{2}$ : Donatur memiliki persepsi bahwa informasi laporan perubahan dana dibutuhkan dalam organisasi pengelolaan zakat. 
Dari tabel 23, dapat diketahui bahwa nilai t hitung adalah $-0,057$. Dengan demikian $\mathrm{t}$ hitung lebih kecil dari $\mathrm{t}$ tabel yang berarti $\mathrm{H}_{0}$ tidak dapat ditolak. Artinya hipotesis II yang menyatakan bahwa laporan perubahan dana merupakan kebutuhan informasi bagi pengguna tidak dapat didukung.

Tabel 9

t-test one sampel untuk Variabel Laporan Perubahan dana

\begin{tabular}{|c|c|c|c|c|c|c|}
\hline & \multicolumn{6}{|c|}{ Test Value $=4$} \\
\hline & \multirow[t]{2}{*}{$\mathrm{t}$} & \multirow[t]{2}{*}{ df } & \multirow[t]{2}{*}{$\begin{array}{l}\text { Sig. } \\
\text { (2-tailed) }\end{array}$} & \multirow[t]{2}{*}{\begin{tabular}{|l} 
Mean \\
Difference
\end{tabular}} & \multicolumn{2}{|c|}{$\begin{array}{l}95 \% \text { Confidence } \\
\text { Interval of the } \\
\text { Difference }\end{array}$} \\
\hline & & & & & Lower & Upper \\
\hline $\begin{array}{l}\text { Laporan } \\
\text { Perubahan }\end{array}$ & -.057 & 137 & .954 & -.00355 & -.1264 & .1193 \\
\hline
\end{tabular}

Sumber: data primer yang diolah

\section{Pengujian Hipotesis III}

$\mathrm{H}_{3}$ : Donatur memiliki persepsi bahwa informasi laporan perubahan aset

Tabel 10

t-test one sampel untuk Variabel Laporan Perubahan Aset Kelolaan

\begin{tabular}{|c|c|c|c|c|c|c|}
\hline & \multicolumn{6}{|c|}{ Test Value $=4$} \\
\hline & \multirow{2}{*}{ Lence } & \multirow[t]{2}{*}{ df } & \multirow[t]{2}{*}{$\begin{array}{l}\text { Sig. } \\
(2 \text {-tailed })\end{array}$} & \multirow[t]{2}{*}{$\begin{array}{l}\text { Mean } \\
\text { Difference }\end{array}$} & \multicolumn{2}{|c|}{$\begin{array}{l}95 \% \text { Confidence } \\
\text { Interval of the } \\
\text { Difference }\end{array}$} \\
\hline & & & & & Lower & Upper \\
\hline $\begin{array}{l}\text { Laporan } \\
\text { Perubahan Aset } \\
\text { Kelolaan }\end{array}$ & 1.025 & 137 & .307 & 2.94203 & -2.7331 & 8.6171 \\
\hline
\end{tabular}

Sumber: data primer yang diolah

Dari tabel 10, dapat diketahui bahwa nilai $t$ hitung adalah 1,025 . Dengan demikian $\mathrm{t}$ hitung lebih kecil dari $\mathrm{t}$ tabel yang berarti $\mathrm{H}_{0}$ tidak dapat ditolak. Artinya hipotesis III yang menyatakan bahwa laporan perubahan aset kelolaan merupakan kebutuhan informasi bagi pengguna tidak dapat didukung.

\section{Pengujian Hipotesis IV}

$\mathrm{H}_{4}$ : Donatur memiliki persepsi bahwa informasi laporan arus kas dibutuhkan dalam organisasi pengelolaan zakat.

Tabel 11

t-test one sampel untuk Variabel Laporan Arus Kas

\begin{tabular}{|c|c|c|c|c|c|c|}
\hline & \multicolumn{6}{|c|}{ Test Value $=4$} \\
\hline & \multirow[t]{2}{*}{$\mathrm{t}$} & \multirow[t]{2}{*}{ df } & \multirow[t]{2}{*}{$\begin{array}{l}\text { Sig. } \\
\text { (2-tailed) }\end{array}$} & \multirow[t]{2}{*}{$\begin{array}{l}\text { Mean } \\
\text { Difference }\end{array}$} & \multicolumn{2}{|c|}{$\begin{array}{l}95 \% \text { Confidence } \\
\text { Interval of the } \\
\text { Difference }\end{array}$} \\
\hline & & & & & Lower & Upper \\
\hline $\begin{array}{l}\text { Laporan } \\
\text { Arus Kas }\end{array}$ & 1.036 & 137 & .302 & 3.72208 & -3.3844 & 10.8285 \\
\hline
\end{tabular}

Sumber: data primer yang diolah

Dari tabel 11, dapat diketahui bahwa nilai $\mathrm{t}$ hitung adalah 1,036 . Dengan demikian $\mathrm{t}$ hitung lebih kecil dari $\mathrm{t}$ tabel yang berarti $\mathrm{H}_{0}$ tidak dapat ditolak. Artinya hipotesis IV yang menyatakan bahwa laporan arus kas merupakan kebutuhan informasi bagi pengguna tidak dapat didukung.

\section{Pengujian Hipotesis V}

$\mathrm{H}_{5}$ : Donatur memiliki persepsi bahwa informasi catatan atas laporan keuangan dibutuhkan organisasi pengelolaan zakat.

Tabel 12

t-test one sampel untuk Variabel Catatan Atas Laporan Keuangan

\begin{tabular}{|l|l|l|l|l|l|l|}
\hline & \multicolumn{5}{|l|}{ Test Value $=4$} & \multicolumn{2}{l|}{} \\
\hline & $\mathrm{t}$ & $\mathrm{df}$ & $\begin{array}{l}\text { Sig. } \\
(2-\text { tailed })\end{array}$ & $\begin{array}{l}\text { Mean } \\
\text { Difference }\end{array}$ & \multicolumn{2}{l|}{$\begin{array}{l}\text { Interval of the } \\
\text { Difference }\end{array}$} \\
\cline { 5 - 7 } & & & & & Lower & Upper \\
\hline $\begin{array}{l}\text { Catatan } \\
\text { Atas Lap } \\
\text { Keu }\end{array}$ & -.328 & 137 & .744 & -.02029 & -.1427 & .1021 \\
\hline
\end{tabular}

Sumber: data primer yang diolah

Dari tabel 12, dapat diketahui bahwa nilai t hitung adalah $-0,328$. Dengan demikian $t$ hitung lebih kecil dari $\mathrm{t}$ tabel yang berarti $\mathrm{H}_{0}$ tidak dapat ditolak. Artinya hipotesis V yang menyatakan 
bahwa catatan atas laporan keuangan merupakan kebutuhan informasi bagi pengguna tidak dapat didukung.

Meskipun melalui pengujian $\mathrm{t}$ secara keseluruhan hipotesis tidak terdukung, peneliti juga melakukan pengujian $t$ tiap item dalam variabel. Hasil pengujian $\mathrm{t}$ tiap item untuk variabel neraca dapat dilihat pada tabel 13 .

Tabel 13

T-test per item untuk variabel Neraca

\begin{tabular}{|c|c|c|c|c|c|c|}
\hline & \multicolumn{6}{|c|}{ Test Value $=4$} \\
\hline & \multirow[b]{2}{*}{$\mathrm{t}$} & \multirow[b]{2}{*}{ df } & \multirow[b]{2}{*}{$\begin{array}{l}\text { Sig. } \\
\text { (2-tailed) }\end{array}$} & \multirow[b]{2}{*}{$\begin{array}{l}\text { Mean } \\
\text { Difference }\end{array}$} & \multicolumn{2}{|c|}{$\begin{array}{l}95 \% \text { Confidence } \\
\text { Interval of the } \\
\text { Difference }\end{array}$} \\
\hline & & & & & Lower & Upper \\
\hline Kas & 5.412 & 137 & .000 & .36957 & . 2345 & .5046 \\
\hline SetaraKas & -1.492 & 137 & .138 & -.12319 & -.2865 & .0401 \\
\hline Piutang & -.370 & 137 & .712 & -.02899 & -.1838 & .1258 \\
\hline $\begin{array}{l}\text { Persediaan } \\
\text { Barang Untuk } \\
\text { Disalurkan }\end{array}$ & -.615 & 137 & .540 & -.05072 & -.2138 & .1124 \\
\hline Aset Tetap & .465 & 137 & 643 & .03623 & -.1179 & .1903 \\
\hline $\begin{array}{l}\text { Hutang } \\
\text { Lembaga Lain }\end{array}$ & .601 & 137 & .549 & .05072 & -.1162 & 2176 \\
\hline $\begin{array}{l}\text { Hutang Pihak } \\
\text { Ketiga }\end{array}$ & -1.185 & 137 & .238 & -.10145 & -.2707 & .0678 \\
\hline $\begin{array}{l}\text { Biaya Masih } \\
\text { Harus Dibayar }\end{array}$ & 1.626 & 137 & .106 & .11594 & -.0251 & .2570 \\
\hline Hutang Gaji & -.890 & 137 & .375 & -.07246 & -.2334 & . 0885 \\
\hline $\begin{array}{l}\text { Saldo Dana } \\
\text { Zakat }\end{array}$ & 6.067 & 137 & . 000 & .36957 & 2491 & . 4900 \\
\hline $\begin{array}{l}\text { Saldo Dana } \\
\text { Infaq }\end{array}$ & 5.770 & 137 & .000 & .35507 & . 2334 & .4768 \\
\hline $\begin{array}{l}\text { Saldo Dana } \\
\text { Operasional } \\
\text { Pegawai }\end{array}$ & 1.026 & 137 & .307 & .07971 & -.0739 & .2333 \\
\hline
\end{tabular}

Sumber: data primer yang diolah

Dari tabel 13 dapat dilihat, untuk item Kas, Saldo Dana Zakat, dan Saldo Dana Infaq memiliki $t$ hitung lebih besar dari $t$ tabel. Data tersebut dapat menjadi dasar bahwa pengguna khususnya donatur memerlukan informasi dari lembaga mengenai Kas, Saldo Dana Zakat, dan Saldo Dana Infaq.
Tabel 14

\section{T-test per item untuk Variabel Laporan} Perubahan Dana

\begin{tabular}{|c|c|c|c|c|c|c|}
\hline & \multicolumn{6}{|c|}{ Test Value $=4$} \\
\hline & & & & & $\begin{array}{l}95 \% \text { Con } \\
\text { Interval } \\
\text { Differenc }\end{array}$ & $\begin{array}{l}\text { idence } \\
\text { f the } \\
\text { e }\end{array}$ \\
\hline & $\mathrm{T}$ & df & $\begin{array}{c}\text { Sig. } \\
\text { (2-tailed) }\end{array}$ & $\begin{array}{c}\text { Mean } \\
\text { Difference }\end{array}$ & Lower & Upper \\
\hline Dana Zakat & 4.964 & 137 & .000 & .34058 & .2049 & .4762 \\
\hline $\begin{array}{l}\text { Bagian Amil dari } \\
\text { Dana Zakat }\end{array}$ & -.757 & 137 & .450 & -.06522 & -.2356 & .1052 \\
\hline $\begin{array}{l}\text { ZakatnTersalur ke } \\
\text { Entitas Lain }\end{array}$ & 4.345 & 137 & .000 & .28261 & .1540 & .4112 \\
\hline $\begin{array}{l}\text { Zakat Tersalur ke } \\
\text { Mustahiq }\end{array}$ & 6.189 & 137 & .000 & .40580 & .2761 & .5354 \\
\hline Infak Khusus & -.773 & 137 & .441 & -.06522 & -.2320 & .1015 \\
\hline $\begin{array}{l}\text { Infak Tidak } \\
\text { Khusus } \\
\end{array}$ & -3.156 & 137 & .002 & -.25362 & -.4126 & -.0947 \\
\hline $\begin{array}{l}\text { Infak Khusus } \\
\text { Tersalur } \\
\end{array}$ & .824 & 137 & .411 & .06522 & -.0913 & .2217 \\
\hline $\begin{array}{l}\text { Infak Tidak } \\
\text { Khusus Tersalur }\end{array}$ & .208 & 137 & .836 & .01449 & -.1234 & .1524 \\
\hline $\begin{array}{l}\text { Dana Amil dari } \\
\text { Infak }\end{array}$ & -.640 & 137 & .523 & -.05072 & -.2074 & .1059 \\
\hline $\begin{array}{l}\text { Penggunaan Dana } \\
\text { Amil }\end{array}$ & -.735 & 137 & .463 & -.05797 & -.2139 & .0979 \\
\hline Dana Non Halal & -1.805 & 137 & .073 & -.16667 & -.3492 & .0159 \\
\hline $\begin{array}{l}\text { Penggunaan Dana } \\
\text { Non Halal }\end{array}$ & -3.079 & 137 & .003 & -.31159 & -.5117 & -.1115 \\
\hline $\begin{array}{l}\text { Dana Zakat } \\
\text { Perseorangan }\end{array}$ & .364 & 137 & .716 & .02899 & -.1285 & .1864 \\
\hline $\begin{array}{l}\text { Dana Zakat } \\
\text { Lembaga }\end{array}$ & 2.116 & 137 & .036 & .15217 & .0099 & .2944 \\
\hline $\begin{array}{l}\text { Dana Zakat } \\
\text { Tersalur Rinci }\end{array}$ & 3.264 & 137 & .001 & .25362 & .1000 & .4073 \\
\hline $\begin{array}{l}\text { Penggunaan Dana } \\
\text { Amil Rinci }\end{array}$ & -1.169 & 137 & .244 & -.10870 & -.2925 & .0751 \\
\hline
\end{tabular}

Sumber: data primer yang diolah

Dari tabel 14 dapat dilihat, untuk item Dana Zakat, Zakat Tersalur ke Entitas Lain, Zakat Tersalur ke mustahiq, Dana Zakat Lembaga, dan Dana Zakat Tersalur Rinci memiliki t hitung lebih besar dari t tabel. Data tersebut dapat menjadi dasar bahwa pengguna khususnya donatur memerlukan informasi dari lembaga mengenai Dana Zakat, Zakat Tersalur ke Entitas Lain, Zakat Tersalur ke mustahiq, Dana Zakat Lembaga, dan Dana Zakat Tersalur Rinci. 
Tabel 15

T-test per item untuk Variabel Laporan Perubahan Aset Kelolaan

\begin{tabular}{|c|c|c|c|c|c|c|}
\hline & \multicolumn{6}{|c|}{ Test Value $=4$} \\
\hline & & & & & $\begin{array}{l}95 \% \text { Confi } \\
\text { Interval of } \\
\text { Difference } \\
\end{array}$ & $\begin{array}{l}\text { dence } \\
\text { the }\end{array}$ \\
\hline & $\mathrm{T}$ & Df & $\begin{array}{l}\text { Sig. } \\
\text { (2-tailed) }\end{array}$ & \begin{tabular}{|l|} 
Mean \\
Difference
\end{tabular} & Lower & Upper \\
\hline $\begin{array}{l}\text { Jumlah Aset } \\
\text { Dikelola }\end{array}$ & 1.178 & 137 & .241 & .08696 & -.0590 & .2329 \\
\hline $\begin{array}{l}\text { Jumlah } \\
\text { Perubahan Aset } \\
\text { Dikelola }\end{array}$ & .735 & 137 & .463 & .05797 & -.0979 & .2139 \\
\hline
\end{tabular}

Sumber: data primer yang diolah

Dari tabel 15 dapat dilihat, tidak ada item yang memiliki $t$ hitung lebih besar dari $t$ tabel sehingga mungkin jumlah aset yang dikelola dan jumlah perubahan aset dikelola bukan merupakan informasi yang dibutuhkan donatur.

Tabel 16

T-test per item untuk Variabel Laporan Arus Kas

\begin{tabular}{|c|c|c|c|c|c|c|}
\hline & \multicolumn{6}{|c|}{ Test Value $=4$} \\
\hline & \multirow[b]{2}{*}{$\mathrm{T}$} & \multirow[b]{2}{*}{ Df } & \multirow[b]{2}{*}{$\begin{array}{l}\text { Sig. } \\
\text { (2-tailed) }\end{array}$} & \multirow[b]{2}{*}{$\begin{array}{l}\text { Mean } \\
\text { Difference }\end{array}$} & \multicolumn{2}{|c|}{$\begin{array}{l}95 \% \\
\text { Confidence } \\
\text { Interval of the } \\
\text { Difference }\end{array}$} \\
\hline & & & & & Lower & Upper \\
\hline $\begin{array}{l}\text { Total Kas dari } \\
\text { Dana ZIS }\end{array}$ & 7.365 & 137 & .000 & .41304 & .3022 & .5239 \\
\hline $\begin{array}{l}\text { Total Penggunaan } \\
\text { Dana ZIS Untuk } \\
\text { Operasional } \\
\text { Kantor }\end{array}$ & 5.347 & 137 & .000 & .32609 & .2055 & .4467 \\
\hline Kas dari Investasi & -.542 & 137 & .589 & -.04348 & -.2022 & .1152 \\
\hline $\begin{array}{l}\text { Kas untuk } \\
\text { investasi }\end{array}$ & .561 & 137 & .576 & .04348 & -.1099 & .1969 \\
\hline $\begin{array}{l}\text { Kas dari } \\
\text { pembiayaan }\end{array}$ & -.370 & 137 & .712 & -.02899 & -.1838 & .1258 \\
\hline $\begin{array}{l}\text { Kas untuk } \\
\text { pembiayaan }\end{array}$ & 1.391 & 137 & .167 & .10145 & -.0428 & .2457 \\
\hline
\end{tabular}

Sumber: data primer yang diolah

Untuk variabel laporan arus kas, hasil t-test per item ditunjukkan dengan tabel 16. Dari tabel tersebut dapat dilihat untuk item Kas dari Dana ZIS dan Total Penggunaan dana ZIS untuk operasional kantor memiliki t hitung lebih besar dari t tabel. Data tersebut dapat menjadi dasar bahwa pengguna khususnya donatur memerlukan informasi dari lembaga mengenai Kas dari Dana ZIS dan Total Penggunaan dana ZIS untuk operasional kantor.

Hasil pengujian t-test per item variabel laporan arus kas ditunjukkan dalam tabel 17. Dari tabel tersebut dapat dilihat, hanya item Program yang sedang dijalankan yang memiliki $t$ hitung lebih besar dari $t$ tabel sehingga Program yang sedang dijalankan mungkin merupakan informasi yang dibutuhkan donatur.

Tabel 17

\section{T-test per item untuk Variabel Catatan Atas Laporan Keuangan}

\begin{tabular}{|c|c|c|c|c|c|c|}
\hline & \multicolumn{6}{|c|}{ Test Value $=4$} \\
\hline & & & & & $\begin{array}{l}95 \% \text { Co } \\
\text { Interval } \\
\text { Differen }\end{array}$ & $\begin{array}{l}\text { nfidence } \\
\text { of the } \\
\text { ce }\end{array}$ \\
\hline & $t$ & Df & $\begin{array}{l}\text { Sig. } \\
\text { (2-tailed) }\end{array}$ & $\begin{array}{l}\text { Mean } \\
\text { Difference }\end{array}$ & Lower & Upper \\
\hline $\begin{array}{l}\text { Struktur } \\
\text { Organisasi }\end{array}$ & -1.376 & 137 & .171 & -.11594 & -.2825 & .0506 \\
\hline $\begin{array}{l}\text { Nomor dan Akte } \\
\text { Pendirian }\end{array}$ & -2.077 & 137 & .040 & -.19565 & -.3819 & -.0094 \\
\hline $\begin{array}{l}\text { Program } \\
\text { yang sedang } \\
\text { Dijalankan }\end{array}$ & 4.199 & 137 & .000 & 26812 & 1419 & .3944 \\
\hline $\begin{array}{l}\text { Kebijakan } \\
\text { Akuntansi }\end{array}$ & -1.000 & 137 & .319 & -.07971 & -.2373 & .0779 \\
\hline $\begin{array}{l}\text { Penjelasan Atas } \\
\text { Pos Laporan } \\
\text { Keuangan }\end{array}$ & .284 & 137 & .777 & . 02174 & -.1297 & .1732 \\
\hline
\end{tabular}

Sumber: data primer yang diolah

Secara ringkas, item dalam laporan keuangan yang memiliki t hitung lebih besar dari $\mathrm{t}$ tabel melalui pengujian $t$-test sebagai berikut:
a. Kas
b. Saldo Dana Zakat
c. Saldo Dana Infaq
d. Dana Zakat
e. Zakat Tersalur ke Entitas Lain
f. Zakat Tersalur ke mustahiq 
g. Dana Zakat Lembaga

h. Dana Zakat Tersalur Rinci

i. Kas dari Dana ZIS

j. Total Penggunaan dana ZIS untuk operasional kantor

k. Program yang sedang dijalankan

Dari item-item tersebut menunjukkan bahwa hal yang menjadi perhatian donatur adalah kemana donasinya disalurkan. Hal tersebut dapat dilihat dari poin e, f, h, j, serta k. Penelitian ini dapat berperan sebagai tindak lanjut survei PIRAC bahwa $70 \%$ masyarakat menginginkan laporan pendayagunaan donasi.

Walaupun donatur merasa tidak memerlukan laporan keuangan sebagai pertanggungjawaban lembaga, OPZ tetap berkewajiban menerbitkan laporan keuangan. Hal ini menyusul ditetapkannya UU Nomor 14 Tahun 2008 tentang Keterbukaan Informasi Publik (Mintarti, 2010). UU Nomor 14 Tahun 2008 mewajibkan agar adanya kemudahan dalam mengakses informasi publik oleh masyarakat. Yang dimaksud informasi publik adalah informasi yang dihasilkan, disimpan, dikelola, dikirim, dan/atau diterima oleh suatu badan publik yang berkaitan dengan penyelenggara dan penyelenggaraan negara dan/atau penyelenggara dan penyelenggaraan badan publik lainnya yang sesuai dengan Undang-Undang ini serta informasi lain yang berkaitan dengan kepentingan publik.

Donatur mungkin tidak meminta laporan keuangan sebagai pertanggungjawaban karena merasa dana yag sudah didonasikan kepada lembaga bukan lagi miliknya tetapi milik Allah yang diwakili umat (Wistoro, 2010). Namun demikian transparansi dan akuntabilitas lembaga melalui laporan keuangan dapat dilakukan melalui media massa yang dapat diakses masyarakat luas. Hal ini sesuai hasil survei UIN Syarif Hidayatullah yang menyebutkan bahwa 75 $\%$ masyarakat enggan menyalurkan zakat pada lembaga yang tidak dikenal baik akuntabilitasnya (infopluz,2007).

\section{KESIMPULAN DAN SARAN}

Hasil penelitian menunjukkan bahwa laporan pendayagunaan donasi yang diinginkan donatur bukan berupa laporan keuangan melainkan hanya beberapa item dari laporan keuangan. Informasi yang dianggap penting oleh pengguna dari lembaga zakat adalah Kas, Saldo Dana Zakat, Saldo Dana Infaq, Dana Zakat, Zakat Tersalur ke Entitas Lain, Zakat Tersalur ke mustahiq, Dana Zakat Lembaga, Dana Zakat Tersalur Rinci, Kas dari Dana ZIS, Total Penggunaan dana ZIS untuk operasional kantor, dan Program yang sedang dijalankan.

Penelitian ini merupakan eksploratif yang belum pernah dilakukan sebelumnya sehingga kebanyakan referensi berupa survei bukan jurnal. Respon hanya dibatasi pada pengguna dengan posisi donatur sedangkan stakeholder untuk lembaga zakat tidak hanya donator. Keterbatasan izin dari lembaga menjadikan peneliti tidak dapat memilih donatur sendiri dan tidak dapat melakukan wawancara langsung sehingga bias pemahaman kuesioner tidak bisa dihindari. Selain itu, penelitian ini hanya mengambil responden di Propinsi Yogyakarta sehingga memungkinkan adanya perbedaan hasil apabila dilakukan di wilayah yang berbeda.

\section{DAFTAR PUSTAKA}

Bastian, Indra. 2006. Akuntansi Sektor Publik: Suatu Pengantar. Penerbit Erlangga. Jakarta.

Detiknews, 2008. MUI Imbau Pembagian Zakat Lewat Organisasi Profesional. Berita. Diakses melalui situs www.detiknews. com

Dwiyanti,Ine. 2007. Pengaruh Penerapan Akutansi Dana dan Aksesibilitas Laporan Keuangan Terhadap Akuntabilitas 
Keuangan LAZ. Diakses melalui www. infopluz.wordpress.com pada 28 Juni 2009.

Exposure Draft Pernyataan Standar Akuntansi Keuangan 109 mengenai Akuntansi untuk Zakat, Infak/Sedekah. Diakses melalui situs www.iaiglobal.go.id pada 24 Februari 2009.

Ghozali, Imam. 2009. Aplikasi Analisis Multivariate dengan Program SPSS. Cetakan IV. Badan Penerbit Universitas Diponegoro. Semarang.

Hafidhudin, Didin, 2008. Panduan Praktis Tentang Zakat, Infaq, Sedekah. Cetakan ketujuh. Gema Insani. Jakarta

Mintarti, Nana (praktisi zakat Dompet Dhuafa Republika). 2010. Hasil wawancara peneliti pada tanggal 11 Mei 2010.

PIRAC (Public Interest Research and Advocacy Center), 2007. Pola dan Potensi Sumbangan Masyarakat. Hasil Survei. Dipublikasikan melalui situs www.pirac. net yang diakses pada 11 November 2009.

Infopluz,2007. Akuntabilitas Lembaga Zakat. Artikel. Diakses melalui situs www. infopluz.wordpress.com pada 28 Juni 2009.

Ketua Forum Zakat, 2010. Hasil wawancara peneliti pada tanggal 13 Februari 2010.

Pedoman Akuntansi Zakat, 2005. Diterbitkan oleh Forum Zakat.

Pernyataan Standar Akuntansi Keuangan No. 45 tentang Pelaporan Organisasi Nirlaba

Qardawi, Yusuf. 2007. Hukum Zakat. Cetakan kesepuluh.Litera AntarNusa. Jakarta.
Republika. 2007. Zakat Punya Standar Akuntansi Sendiri. Berita. Diakses melalui blog Supriyanta pada 18 Juni 2009.

Sudewo, Erie. 2004. Manajemen Zakat. Cetakan Pertama. Institut Manajemen Zakat. Jakarta.

Suwardjono. 2008. Pengujian Hipotesis tentang Mean Populasi. Slide power point. Disampaikan pada kuliah Statistika Lanjutan mahasiswa Program Msi UGM Angkatan Mei 2008.

Tearney-Dodd-Wolk. 2004. Accounting Theory, Conceptual Issues in a Political and Economic Environment. Thomson. South-Western.

Tulus. 2007. Sejarah Pengelolaan Zakat di Indonesia. Makalah. Disampaikan pada kuliah Zakat Executive Development Program 2 yang diselenggarakan LAZ Dompet Dhuafa Republika pada tanggal 30 Juli 2007.

Undang-Undang No.38 Tahun 1999 tentang Pengelolaan Zakat.

Undang-Undang No.14 Tahun 2008 tentang Keterbukaan Informasi Publik.

Weinstein, Edward A. 1978. Forging Nonprofit Accounting Principle. Accounting Review Vol.53 diakses melalui http:// www.jstor.org/stable/246312 pada 25 Juli 2009.

Wistoro, Daru Lalito (praktisi zakat Dompet Dhuafa Republika). 2010. Hasil wawancara peneliti tanggal 12 Mei 2010. 